\title{
ПЕРЕВАГИ ЗАСТОСУВАННЯ КОНЦЕПЦІЇ ІНФОРМАЦІЙНОГО МОДЕЛЮВАННЯ В БУДІВНИЦТВІ
}

\section{ADVANTAGES OF APPLICATION OF THE CONCEPT OF BUILDING INFORMATION MODELING}

Tрач P.B., к. е. н. orcid.org/0000-0001-6654-9870 (Варшавський університет природничих наук, Польща, Варшава)

Roman Trach, PhD in Economics orcid.org/0000-0001-6654-9870 (Warsaw Uniwersity of Life Sciences, Warsaw, Poland)

В статті досліджено цільові засади концепцій інформаційного моделювання в будівництві (BIM). Проаналізовано та систематизовано складнощі та вигоди, які можуть виникати при запровадженні інформаційного моделювання. Сформульовано конкурентні переваги, які отримують учасники інвестиційно-будівельного процесу від застосування BIM.

Industry inclination and implementation towards building information modeling (BIM) is rapidly increasing as different governments support BIM initiatives and have set BIM as a requirement. In Ukraine building information modeling is mostly used by companies and software developers. Technologies of building information modeling are slowly, but constantly developing, they are focused on private enterprises and are not supported by the state. The use of building information modeling has several advantages compared with classical methods of architectural and building modelling. Building information modeling in the construction industry is a process involving the generation, processing and management of digital representations of physical and functional characteristics of buildings and places. Building information models are files containing proprietary construction, technological, economic and other data, which can be extracted, exchanged or networked to support decision-making regarding a building or other built asset.

Basic principles of building information modeling (BIM) concepts in the field of construction are studied. Challenges, risks and benefits that can arise in the result of information modeling implementation are analyzed. Competitive advantages that participants of investment and construction process can achieve due to BIM applying are characterized. 


\section{Ключові слова:}

Інформаційне моделювання, ВIM, будівельний проект, концепція, інтеграція. Information Modeling, BIM, construction project, concept, integration.

Вступ. Концепція ВIM виступила в якості альтернативи існуючої традиційної САПР. Нова система пропонує одночасно великі інтелектуальні переваги та можливість взаємодії всіх учасників будівельного процесу [1]. Цифрове подання фізичних i функціональних характеристик об'єкта дозволяють користувачам передавати проектні дані і специфікації як між різними програмними додатками, так і в одній організації або в рамках багатопрофільної групи. Вся доступна про об'єкти інформація зберігається в базі даних BIM і в міру необхідності може бути доступна протягом усього життєвого циклу об'єкта.

Аналіз останніх досліджень. ВІМ був ідентифікований як "технологія генерації та управління параметричної моделлю будівлі" [2]. Він також згадується як розвивається багатогранний феномен з об'єктно-орієнтованої 3D-моделлю структури для забезпечення інтероперабельності та обміну інформацією [3]. Таким чином, ВIM - це зростаюча область теорії і практики, яка об'єднує різні галузі знань будівельної галузі [4]. Інструменти ВIM забезпечують оптимізацію процесів параметричного моделювання об'єктів, створення нових рівнів просторової візуалізації, моделювання «поведінки» будівель, ефективне управління проектом і оперативне співробітництво між членами команди. ВIМ відноситься до набору технологій і рішення, які можуть сприяти між організаційного співпраці і підвищення продуктивності в будівельній галузі, а також поліпшенню дизайну, будівництва та обслуговування об'єкта. Технології ВІМ постійно розширюють і розвивають нові функціональні можливості. Інструменти ВIM дозволяють отримати вичерпну інформацію про критерії, які повинні бути враховані під час процесу проектування, починаючи від окремих компонентів і розташування будівлі і закінчуючи стосунками між цими критеріями. ВІМ включає в себе інформацію про будівництво, починаючи від геометрії, просторових зв'язків, аналізу висвітлення, географічної інформації, кількості і властивості будівельних матеріалів і комплектуючих, специфікації, вогнестійкості, вартості. Хоча переваги ВIM неявно розуміються дизайнером, вони можуть стати явними для інших учасників проекту, таких як власники, підрядники, субпідрядники, оздоблювальні компанії. У разі змін дизайну інструменти BIM можуть інтегрувати і систематизувати зміни в цілому проект [5]. Більш того, ВІМ може використовуватися для інтеграції управління об'єктами.

Результати досліджень. Протягом останніх десятиліть складність будівельних проектів значно зросла [6]. Щоб «йти в ногу з часом» і сприяти розвитку інновацій в будівництві інформаційні технології (IT) i інформаційно-комунікаційні технології (ІКТ) повинні так само активно розвиватися [7]. ВIM був розроблений, як система здатна полегшити 
проектування, будівництво і технічне обслуговування об'єкта будівництва за допомогою комплексного підходу. Він забезпечує спільну платформу для всіх зацікавлених сторін, що беруть участь в реалізації проекту. Власники, дизайнери, підрядники та менеджери з будівництва можуть використовувати BIM для більш ефективного будівництва, ніж будь-коли раніше [8]. Крім того, інноваційні інструменти IT / IКТ є важливими факторами в навчанні і розвитку будівельної галузі. С прогнозне пропозицію, що ВIM теж буде використовуватися для інтеграції знань і поліпшення навчання [9]. ВIМ може використовуватися в якості інтерактивного керівництва для безпечного управління і експлуатації будівлі, що надає повну інформацію про об'єкті [10], наприклад, фізичну структуру, механічні та електричні системи, внутрішній дизайн. За допомогою ВIM можна змоделювати процес технічного обслуговування або модифікації об'єкта [11], що природним чином поліпшити процес експлуатації, знизить рівень витрат на управління [12], за рахунок більш точної кошторису на проведення ремонтів та реновацій [13]. ВIM також можна використовувати для моделювання сценаріїв евакуації і поведінки натовпу при позаштатних ситуаціях [14]. За рахунок використання ВIM можна більш точно розрахувати кількість будівельних матеріалів і комплектуючих, необхідних для реалізації проекту [15]. Це може допомогти скоординувати процес закупівель на етапах проектування і будівництва [16]. Модель ВIM може використовуватися як джерело інформації для автоматизованих машин при виготовленні готових будівельних комплектуючих [17]. Моделювання процесу будівництва і прив'язка моделі до мережевому графіку дозволяє виявляти різні колізії та нестиковки ще на початкових етапах реалізації проекту, до фактичного початку процесу будівництва [18]. Широке використання ВIМ-інструментів при моделюванні будівель зі складною концепцією дизайну [19] надають архітекторам велику свободу для творчості. У перспективі ВІМ вважається ключовим рішенням при будівництві та експлуатації інтелектуальних будівель [20]. Також ВIM був ідентифікований як інструмент, який може забезпечити значні економічні вигоди. Потужним драйвером для впровадження інноваційних технологій в практику $є$ позитивні фінансові показники. Дослідження показали, що найбільшою мірою ВIM впливає на запобігання відставання графіка будівництва та запобігання переробок на основі ранньої оцінки моделі.

Користувачі BIM визначили як короткострокові, так і довгострокові переваги використання ВIM. Найбільш важливим короткостроковим перевагою ВІМ була мінімізація помилок в документації. Наступна перевага можливість використання BIM в якості маркетингового інструменту. Більш низька плинність кадрів також розглядається як короткострокова вигода від використання BIM. Менша кількість контрактних претензій і скорочення витрат на будівництво розглядаються як довгострокові вигоди. Довгострокове співробітництво $з$ клієнтами також $є$ основним переваг ВIM 
[21]. Також ВIM може використовуватися для початкового планування i техніко-економічної оцінки. Концептуальна модель будівлі може включати інформацію про витрати, яка допомагає розробникам при визначенні того, чи може бути споруджено будинок певного розміру, рівня якості і бажаних вимог в рамках конкретного бюджету витрат і часу. Крім того, модель 3D BIM забезпечить більш реалістичну візуалізацію дизайну на всіх етапах реалізації проекту. Мережеві графіки BIM рівня 4D $\epsilon$ потужним інструментом для фазирования, координації та передачі інформації про плановану роботі учасникам проекту [22]. Оскільки всі матеріали і комплектуючі зумовлені і розраховані автоматично, $\epsilon$ можливість їх замовляти через електронну форму і доставляти на будівельний майданчик по мене необхідності, що зменшує витрати і підвищує продуктивність праці. 3D-модель забезпечує прийнятну візуалізацію робочого простору, в той час як мережевий графік 4D пропонує спрощене розуміння різних вимог протягом усього життєвого циклу проекту. Це особливо корисно для зацікавлених сторін, які несуть пряму відповідальність за виконання робіт по будівництву. ВІМ має можливість пов'язувати дані виробників, дані про будівництво та комунікації 3 одного повністю інтегрованою панеллю приладів. Ключовим аспектом будь-якої системи візуалізації є полегшення інтерактивних оновлень в режимі реального часу. Неефективність при виконанні оновлень виключає переваги застосування такої технології. Непослідовні поновлення роблять моніторинг і використання проекту більш складними, що може привести до того, що члени команди втратять трек [23]. В майбутньому очікується, що інструменти BIM забезпечать плавне оновлення в реальному часі і достатню продуктивність візуалізації, щоб забезпечити ефективну взаємодію між членами команди [24].

Багатодисциплінарного інтеграція учасників проекту дозволяє виявляти i вирішувати проблеми до початку етапу будівництва. Це важливо як для розробки нових об'єктів, так і для інтеграції нових об'єктів з існуючими. Рання міждисциплінарна інтеграція дозволяє уникнути непотрібних витрат і часу за рахунок скорочення помилок і запитів на отримання інформації $\mathrm{i}$, отже, скорочення змін.

Building Information Modeling - це розширений метод передачі інформації про проект будівництва. Цей обмін може відбуватися між різними учасниками на протязі всього життєвого циклу проекту. У будівельній галузі чітко видно ознаки фрагментації і поділу різних робіт на етапи, тому при впровадженні нових процесів можна очікувати виникнення бар'єрів і проблем. Швидка і точна ідентифікація потенційних проблем має вирішальне значення, оскільки вона дозволить учасникам проекту зробити відповідні кроки, необхідні для їх пом'якшення і забезпечення успіху проекту.

Фактори комунікації і обміну потоками інформації дуже важливі при реалізації будівельних проектів. Традиційно це робилося у вигляді двовимірних малюнків і паперової документації. Концепція ВІМ передбачає 
використовується інформаційної моделі не тільки як інструмент проектування, але i як інтерфейс для обміну інформацією між різними учасниками на всіх етапах проекту. Розрізнений характер будівельній галузі призвела до необхідності використання різних інструментів управління проектуванням і будівництвом. Кожен учасник проекту надає перевагу інструменти, які спеціалізуються і адаптуються до його індивідуальним ролям.

Така ж ситуація була і при розробці інструментів BIM, коли кожен 3 учасників проекту використовував програмне забезпечення, які погано взаємодіяв один з одним.

- формат даних 3 відкритою специфікацією, яка не контролюється ні однією компанією або групою компаній. Формат файлу був розроблений buildingSMART (International Alliance for Interoperability, IAI) для спрощення взаємодії в будівельній індустрії. Використовується як формат для інформаційної моделі будівлі (Building Information Modeling). Це призвело до впровадження формату даних з відкритою специфікацією IFC (англ. Industry Foundation Classes), міжнародного стандарту з відкритим вихідним кодом. Формат файлу був розроблений buildingSMART (International Alliance for Interoperability, IAI) для спрощення взаємодії при використанні BIM.

Рівень очікувань від використання ВIM в проекті варіюється в залежності від ролі учасника проекту і розміру підприємства. Проектанти очікують, що BIM стане подальшою розробкою і поліпшенням 2D CAD. Конструктори розглядають BIM як інструмент, який полегшує управління документами i інформацією. Чим більше розмір підприємства, тим більше гнучкості воно хоче від програмного забезпечення, щоб мати можливість реалізовувати більші і складні проекти. Різниця в очікуванні від BIM, швидше за все, є результатом відсутності консенсусу щодо того, що таке ВIM. Більшість професіоналів галузі згодні 3 тим, що ВIM складається 3 тривимірних моделей, багатих інформацією, проте точні способи, за допомогою яких ВIM впливає на робочі процеси, є невизначеними. Передача інформації ВIM може бути використана всіма учасниками проекту по всім дисциплін протягом всього життєвого циклу. Важливо відзначити, що в проекті сам ВIM не є метою, а радше засобом досягнення цілей. Проектні команди повинні розробити план використання ВIM в проекті на самій ранній стадії його реалізації. Це дозволить їм визначити всі можливі способи використання ВIM для досягнення цілей проекту. Після чіткого визначення цілей проекту всі основні учасники повинні домовитися про обмін інформацією протягом усього періоду його реалізації. Комплексний і продуманий план виконання проекту за допомогою ВІМ є ключовим фактором для забезпечення того, щоб всі учасники проекту були «на одній сторінці» і працювали спільно для реалізації проекту при дотриманні встановлених термінів і бюджету.

BIM, як спільний підхід до планування, проектування, будівництва та управління об'єктами вимагає, щоб інвестори, підрядники, кінцеві 
користувачі і менеджери об'єктів були включені в процес розробки найактивнішим чином. Ключові учасники повинні мати можливість додавати, вилучати, оновлювати або змінювати інформацію в моделі будівлі протягом усього життєвого циклу. У багатьох учасників проекту $\epsilon$ одночасний доступ і можливість внесення змін в проектну документацію.

У зв'язку з цим повинна бути реалізована ефективна система управління проектом з допомогу в веб-платформа для багатопрофільної спільної роботи. Багато постачальників пропонують такі рішення, як: ConjectPM, ThinkProject, Trimble Connect, A360 i т. Д. Ці продукти дозволяють користувачам відстежувати зміни і переконається, що всі працюють 3 актуальними i оновленими документами. Крім того, учасники проекту можуть швидко і легко обмінюватися інформацією один 3 одним, усуваючи необхідність використання паперових носіїв. Найголовніше, платформа служить в якості сховища даних, де вся інформація про проект може надійно зберігатися.

Висновок. Таким чином, технологія BIM сама по собі не поліпшить процес будівництва, але створить можливості для значно більш ефективного і спільного процесу проектування. Необхідно, щоб всі учасники проекту розуміли мету використання ВIM в проекті. Успіх проекту більше залежить від самого слабкого учасника, ніж від самого сильного. Навчання всіх зацікавлених сторін використання інструментів BIM стає вирішальним для успіху проекту. Крім того, розуміння цілей і використання ВIM в проекті повинно бути ефективно визначено на самому ранньому етапі i на найвищому керівному рівні. Це всеосяжне розуміння потім «просочиться» до інших членів команди проекту. Для забезпечення того, щоб для кожної цілі проекту були обрані відповідні варіанти використання ВIM, існує необхідність для створення i використання посади менеджера ВIM. Менеджер ВIM буде відповідати за координацію всього робочого процесу між учасниками проекту і контролювати його виконання. Менеджер ВIM несе пряму відповідальність за забезпечення реалізації ВIM в проекті відповідно до Плану виконання проекту ВIM.

1. Lee Sacks R, Eastman CM. Specifying parametric building object behavior (BOB) for a building information modeling system. Automation in Construction 2006;15:758-76.

2. Son H, Lee S, Kim C. What drives the adoption of building information modeling in design organizations? An empirical investigation of the antecedents affecting architects' behavioral intentions. Automation in Construction 2015;49, [Part A:92-9].

3. Miettinen R, Paavola S. Beyond the BIM utopia: approaches to the development and implementation of building information modeling. Automation in Construction 2014;43:84-91.

4. Succar B. Building information modelling framework: a research and delivery foundation for industry stakeholders. Automation in Construction 2009;18:357-75.

5. Autodesk. White paper: building information modeling. San Rafael: Autodesk building industry solutions; 2002.

6. Chien K-F, Wu Z-H, Huang S-C. Identifying and assessing critical risk factors for BIM projects: empirical study. Automation in Construction 2014;45:1-15. 
7. Bryde D, Broquetas M, Volm JM. The project benefits of Building Information Modelling (BIM). International Journal of Project Management 2013;31:971-80.

8. Ganah A, John GA. Integrating Building Information modeling and health and safety for onsite construction. Saf Health Work 2015;6:39-45.

9. Salama AM. Spatial design education: new directions for pedagogy in architecture and beyond. New York, USA: Taylor \& Francis; 2016.

10. Wetzel EM, Thabet WY. The use of a BIM-based framework to support safe facility management processes. Automation in Construction 2015;60:12-24.

11. Khaddaj M, Srour I. Using BIM to retrofit existing buildings. Procedia Engineering 2016;145:1526-33.

12. Love E.D., Steve Lockley J.M., Kassem P., Kelly M., Dawood G., Serginson N.M. et al. BIM in facilities management applications: a case study of a large university complex. Built Environment Project and Asset Management 2015;5:261-77.

13. Cheng JC, Ma LY. A BIM-based system for demolition and renovation waste estimation and planning. Waste Manag 2013;33:1539-51.

14. Rüppel U, Schatz K. Designing a BIM-based serious game for fire safety evacuation simulations. Advanced Engineering Informatics 2011;25:600-11.

15. Irizarry J, Karan EP, Jalaei F. Integrating BIM and GIS to improve the visual monitoring of construction supply chain management. Automation in Construction 2013;31:241-54.

16. Grilo A, Jardim-Goncalves $\mathrm{R}$. Challenging electronic procurement in the AEC sector: a BIM-based integrated perspective. Automation in Construction 2011;20:107-14.

17. $\mathrm{Lu} \mathrm{N}$, Korman $\mathrm{T}$. Implementation of building information modeling (BIM) in modular construction: benefits and challenges. In: Proceedings of the construction research congress, Banff, Alta; 2010. p. 8-10.

18. Azhar S, Khalfan M, Maqsood T. Building Information Modelling (BIM): now and beyond. Constr Econ Build 2015;12:15-28.

19. Johansson M, Roupé $M$, Bosch-Sijtsema P. Real-time visualization of building information models (BIM). Automation in Construction 2015;54:69-82.

20. Ghaffarianhoseini A, Berardi U, AlWaer H, Chang S, Halawa E, Ghaffarianhoseni A, et al. What is an intelligent building? Analysis of recent interpretations from an international perspective. Archit Sci Rev 2015:1-20.

21. Bernstein HM, Jones S, Russo M. The business value of BIM in North America: multi-year trend analysis and user rating (2007-2012). SmartMark Rep 2012.

22. Kymmell W. Building Information Modeling: Planning and Managing Construction Projects with 4D CAD and Simulations (McGraw-Hill Construction Series): Planning and Managing Construction Projects with 4D CAD and Simulations. New York, USA: McGraw-Hill Education; 2007

23. Yuan P, Green M, Lau RW. A framework for performance evaluation of real-time rendering algorithms in virtual reality. In: Proceedings of the ACM symposium on virtual reality software and technology: ACM; 1997. p. 51-58.

24. Johansson M, Roupé $M$, Bosch-Sijtsema P. Real-time visualization of building information models (BIM). Automation in Construction 2015;54:69-82. 